\title{
Radiative Impact of Fireworks at a Tropical Indian Location: A Case Study
}

\author{
B. P. Singh, ${ }^{1}$ A. K. Srivastava, ${ }^{2}$ S. Tiwari, ${ }^{2}$ S. Singh, ${ }^{3}$ R. K. Singh, ${ }^{1}$ D. S. Bisht, ${ }^{1,2}$ \\ D. M. Lal, ${ }^{1,2}$ A. K. Singh, ${ }^{4}$ R. K. Mall, ${ }^{5}$ and Manoj K. Srivastava ${ }^{1}$ \\ ${ }^{1}$ Department of Geophysics, Banaras Hindu University, Varanasi 221005, India \\ ${ }^{2}$ Indian Institute of Tropical Meteorology (Branch), Prof. Ram Nath Vij Marg, New Delhi 110060, India \\ ${ }^{3}$ Radio and Atmospheric Sciences Division, National Physical Laboratory, New Delhi 110012, India \\ ${ }^{4}$ Department of Physics, Banaras Hindu University, Varanasi 221005, India \\ ${ }^{5}$ Institute of Environment and Sustainable Development, Banaras Hindu University, Varanasi 221005, India
}

Correspondence should be addressed to Manoj K. Srivastava; mksriv@gmail.com

Received 22 August 2013; Accepted 21 October 2013; Published 22 January 2014

Academic Editor: Sachin D. Ghude

Copyright (C) 2014 B. P. Singh et al. This is an open access article distributed under the Creative Commons Attribution License, which permits unrestricted use, distribution, and reproduction in any medium, provided the original work is properly cited.

\begin{abstract}
During Diwali festival, extensive burning of crackers and fireworks is made. Weeklong intensive observational campaign for aerosol study was carried out at a representative urban location in the eastern Indo-Gangetic Plain (IGP), Varanasi $\left(25.3^{\circ} \mathrm{N}, 83.0^{\circ} \mathrm{E}\right)$, from October 29 to November 04, 2005 (Diwali on November 01, 2005), to investigate behavioral change of aerosol properties and radiative forcing between firework affected and nonaffected periods. Results show a substantial increase ( 27\%) in aerosol optical depth, aerosol absorption coefficients, and aerosol scattering coefficients during affected period as compared to non-affected periods. Magnitudes of radiative forcing at top of atmosphere during affected and non-affected periods are found to be $+10 \pm 1$ and $+12 \pm 1 \mathrm{Wm}^{-2}$, respectively, which are $-31 \pm 7$ and $-17 \pm 5 \mathrm{Wm}^{-2}$, respectively, at surface. It suggests an additional cooling of $\sim 20 \%$ at top of atmosphere, $\sim 45 \%$ cooling at surface, and additional atmospheric heating of $0.23 \mathrm{Kday}^{-1}$ during fireworks affected period, which is $\sim 30 \%$ higher than the non-affected period average.
\end{abstract}

\section{Introduction}

Importance of aerosols in regional and global climate has gained wide knowledge base during the last couple of decades. General impact of these aerosols is to cool the atmosphere and to compensate the atmospheric warming caused due to enhanced greenhouse gases. However, atmospheric warming due to aerosols is also noticed when absorbing particles, such as black carbon (soot) and/or mineral dust, are present $[1,2]$. Significant heating to the atmosphere may play a crucial role in various boundary layer processes under favorable atmospheric conditions [3]. The presence of such aerosols is higher in the atmospheric boundary layer [4], but they are also reported in the free troposphere till stratosphere. Boundary layer aerosols are characterized as short-lived and showed spatiotemporal variation in mass and number concentrations. Depending on weather condition and location, the regional variability in physical, chemical, and optical characteristics of aerosols is influenced by mixing various types of aerosols, produced by different natural and/or anthropogenic processes $[3,5]$, for example, aerosol production from biomass burning [6], biogenic production [7], industrial effluents [8], and so forth. The impact of aerosol is also found to be associated with climatic elements [9].

During recent decades, there have been a number of studies to characterize aerosols on local scale; however, studies on instant increment of aerosols within 1-2 days, due to fireworks, are available for only a few locations, for example, during New Year event [10], Millennium festival [11], Diwali festival [12-14], and so forth. Further, studies reported for firework generated aerosols are more inclined towards the impact of firework generated, gaseous as well as particulate, pollutants on health $[15,16]$, air quality $[12-$ $14,16,17]$, number and mass concentration $[10,11]$, and 
interrelationship between gaseous pollutants and particles $[10,18]$, but the impact of fireworks generated aerosols on climate in terms of atmospheric forcing has never been assessed for any location so far.

The present study is an attempt to understand the changes in optical characteristics of aerosols and also to understand changes in radiative impacts that are caused due to mixing firework generated aerosols in the ambience. Data for this intensive observation period (IOP) was collected for an urban location in Indo-Gangetic Plain (IGP), Varanasi (25.3N, 83.0E, 76 above mean sea level), during October 29 to November 04, 2005 (Diwali was celebrated on November 01). The objectives of the work are to broaden our understanding towards the effect of fireworks on climate and also to quantify their impact in terms of radiative forcing. To the best of our knowledge, this is the first time to report the impact of firework generated aerosol on radiative balance and heating of the atmosphere.

\section{Site Description, Weather, and Data}

Varanasi is a representative urban station in the central part of IGP. Varanasi is amongst few locations in India for which the column ozone and solar ultraviolet radiation are observed along with surface weather parameters, by the office of India Meteorological Department (IMD) at BHU, Varanasi, for the purpose of global database at World Ozone and Ultraviolet Radiation Data Centre (WOUDC). Weather parameters for the present study are obtained from surface weather observatory being managed by IMD, BHU, Varanasi.

Surface weather parameters and aerosol optical depths (AODs) are collected at every half-to-one hour interval during the entire campaign that includes the pre- and postDiwali period. Weather was mostly calm and stable during the IOP. Mean sea level pressure during this period varied from 1011 to $1016 \mathrm{hPa}$ and wind was mostly calm. For the IOP, daily maximum and daily minimum surface temperature and relative humidity varied from 29.0 to $31.0^{\circ} \mathrm{C}$, 11.1 to $19.0^{\circ} \mathrm{C}$, and $67 \%$ to $89 \%$, respectively. General weather of Varanasi during IOP is, however, shown in Figure 1.

Multiwavelength AODs have been collected using MicroTOPS-II. The MicroTOPS-II used in this study was compared with another set of MicroTOPS-II at the National Physical Laboratory, New Delhi (NPL), before IOP. MicroTOPS-II at NPL was calibrated at Solar Light Company, USA, in 2004. More details for comparison, however, can be found elsewhere [19]. AODs were measured at 340,500 , and $870 \mathrm{~nm}$ wavelengths (full width at half maximum: $\pm 2-10 \mathrm{~nm}$ ) and signals at 936 and $1020 \mathrm{~nm}$ are used to compute columnar water vapor (CWV). As per Morys et al. [20], pointing accuracy of the MicroTOPS-II is better than 0.10 and long-term stability of the filter used in the instrument is better than $0.1 \mathrm{~nm}$ per year. In order to check the repeatability of the instrument, frequent observations were taken at about 11 seconds interval on a fairly clear forenoon of October 30, 2005. This series of observation showed average and standard deviations of AODs at 340, 500, and $870 \mathrm{~nm}$ as $1.213 \pm 0.013,0.967 \pm 0.009$, and $0.403 \pm 0.005$,

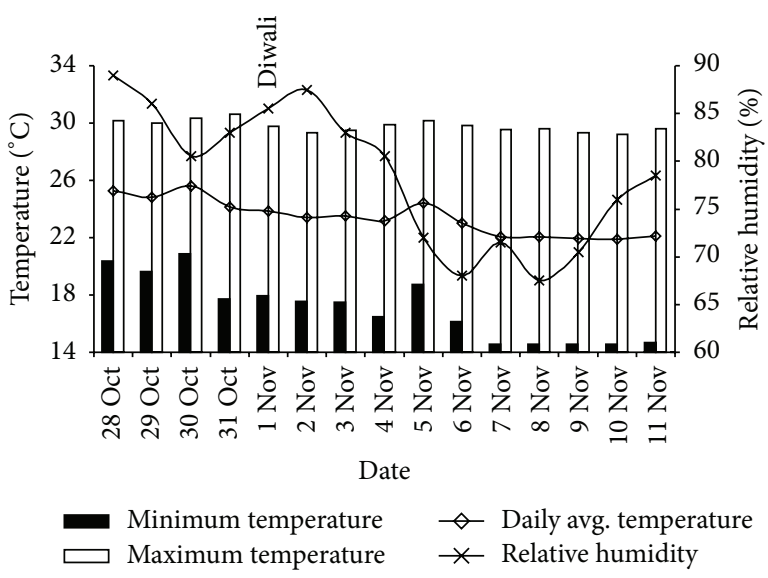

Figure 1: Weather parameters from October 28 till November 11, 2005 at Varanasi.

respectively, over $\sim 7$ minutes of continuous measurements. This suggests that the observations made during IOP are consistent and can be considered as possessing good quality.

The spectral variations of AODs provide useful information on columnar size distribution of aerosols, which can be represented by Ångström power law [21] as,

$$
\tau_{a}(\lambda)=\beta \lambda^{-\alpha},
$$

where $\tau_{a}(\lambda)$ is AOD at wavelength $\lambda$ (in $\mu \mathrm{m}$ ), $\beta$ is turbidity coefficient, and $\alpha$ is Ångström exponent (AE). $\alpha$ is a good indicator of size range of the dominant particle population in an aerosol sample $[22,23]$, and turbidity coefficient $(\beta)$ indicates total aerosol loading, which is equal to aerosol optical depth $\left(\tau_{a}\right)$ at $1.0 \mu \mathrm{m}$ wavelength.

First order derivative of $\alpha$ (i.e., $\alpha^{\prime}$ ) is a derived parameter, which is calculated using more than two wavelengths. This parameter is useful for the estimation of type of aerosols [19]. In the present study, $\alpha^{\prime}$ is computed using AODs obtained at central wavelengths of 340,500 , and $870 \mathrm{~nm}$.

\section{Methodology}

AODs, single scattering albedo (SSA), and asymmetric parameter (AP) are crucial aerosol properties for the estimation of aerosol direct radiative forcing (DRF). Since direct measurements of SSA and AP were not available at Varanasi, these parameters have been estimated using standard procedures (described in next section) of Optical Properties of Aerosols and Clouds (OPAC) model [24].

3.1. Estimation of Aerosol Optical Parameters. OPAC model provides wide range of optical and microphysical properties of aerosols pertaining to 61 discrete wavelengths (between 0.3 and $40 \mu \mathrm{m}$ ), eight values of $\mathrm{RH}$, and various aerosol compositions. We have followed an approach that uses the available measurements as anchoring point in standard continental average aerosol model of OPAC, which is then finetuned to match the measurement in order to derive optical properties of aerosols (see [5] for details). As measured 

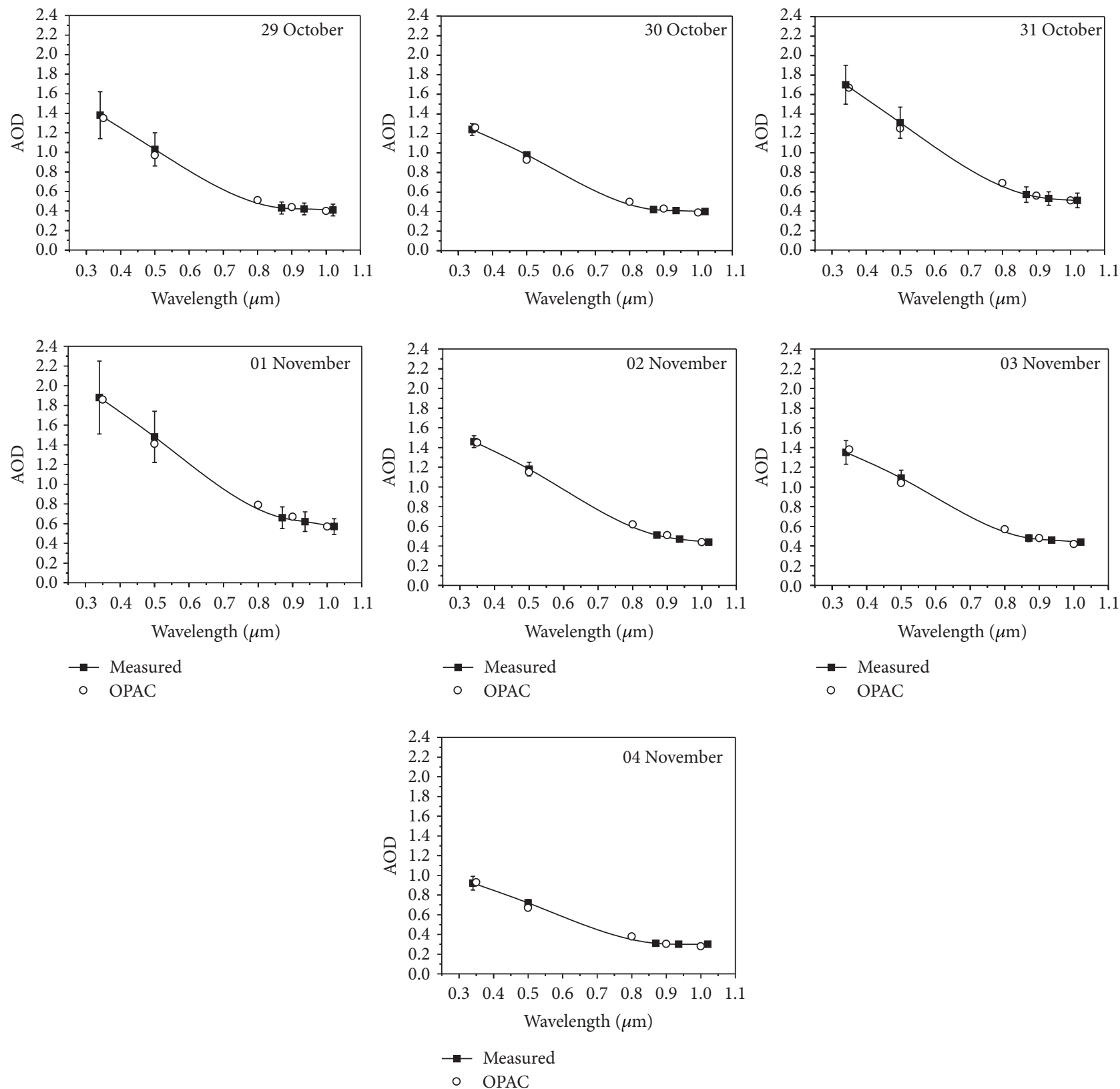

FIGURE 2: Comparison between measured and model (OPAC) derived spectral AODs for intensive observation period (IOP, October 29 to November 04, 2005).

aerosol composition over the station was not available during the study period, we have assumed possible composition in the OPAC model. Once an appropriate atmosphere is generated in OPAC model, measured AODs from MicroTOPSII were used as a reference to constrain other crucial aerosol optical parameters (i.e., SSA and AP). Comparison of OPAC derived and measured spectral AODs are shown in Figure 2. Modelled spectral AOD values were found to be lying within standard deviations of measured spectral AODs, for all the days during IOP. Difference between observed and modelled values was found within $5 \%$.

Using the above-mentioned approach, OPAC model is run for each day of IOP. Though this is an alternative method to derive crucial aerosol optical parameters in the absence of observations, it is an established and widely used method in the literature ([5] and references therein). In this method, however, there are chances of uncertainties due to vertical aerosol distribution. In the absence of vertical aerosol profiles, as in the present case, the surface aerosol properties are attributed to column properties, assuming vertical profiles in OPAC model, as suggested by Srivastava et al. [5]. Additionally, uncertainties may also be generated due to OPAC accounted external mixtures of different aerosol components to form aerosol types. Being an urban station in the central part of IGP, the probability of internal mixing or coating of aerosols may be possible, which can deliver certain uncertainties in the end result. 
3.2. Estimation of Aerosol Direct Radiative Forcing. Aerosols are significant contributors to direct radiative forcing (DRF). Some of these particles, for example, BC and mineral dust, show absorbing nature $[1,2]$ and contribute significantly to the warming of lower atmosphere due to short-wave absorption [25]. In the present study, net flux is computed in the shortwave region $(0.30-3.0 \mu \mathrm{m})$, separately for top of atmosphere (TOA) and surface, with and without aerosols, using the Santa Barbara DISORT atmospheric radiative transfer (SBDART) model [26]. The input parameters for SBDART model are spectral AOD, SSA, and AP, which are either measured or obtained by OPAC model. SBDART uses six standard atmospheres to consider vertical profiles of atmospheric parameters, such as average temperature, pressure, water vapor, and ozone density [26]. Location of Varanasi falls in the tropical classification, which is characterized by average water vapor of $4.117 \mathrm{~g} \mathrm{~cm}^{-2}$ and average columnar ozone of 253 DU. These data are close to observations over Varanasi during October-November months. Surface albedo over the station was considered to be 0.18 , which is slightly less in comparison to Kanpur (an industrial city situated $\sim 300 \mathrm{~km}$ away from Varanasi) [27].

Diurnal average of aerosol direct radiative forcing (DRF) at TOA and at surface is estimated by computing the difference in net radiative fluxes, with and without aerosol, respectively, at TOA and surface. The difference between TOA and surface forcing is considered as atmospheric forcing $(\Delta F)$, which represents the amount of energy trapped or absorbed by aerosols within the atmosphere and which is available to be transformed into heat.

\section{Results and Discussion}

4.1. Aerosol Optical Characteristics. Figure 3 shows measured $\mathrm{AOD}$ at 340,500 , and $870 \mathrm{~nm}$ wavelengths, along with the Ångström exponents $(\alpha)$, computed for the wavelength pair of $340-870 \mathrm{~nm}$ and $\alpha^{\prime}$ (computed with the help of wavelength pairs $340-500 \mathrm{~nm}$ and $500-870 \mathrm{~nm}$ ). By and large, opposite behavior is observed between AOD and $\alpha[12,28$, 29]. AOD was found to increase (with decreasing $\alpha$ ) from October 30 till November 01 (Diwali) and decrease (with increasing $\alpha$ ) on subsequent days (Table 1 and Figure 3). Results suggest enhanced loading of aerosols during Diwali period, most probably due to excessive burning of firework and crackers $[10-12,30] . \alpha^{\prime}$ is a parameter that provides information on types of aerosol in the aerosol population [19]. Positive $\alpha^{\prime}$ is an indicator of fine/accumulation-mode particles dominance, whereas negative $\alpha^{\prime}$ suggests dominance of coarse-mode aerosol particles [19, 31-34]. Table 1 shows that $\alpha^{\prime}$ is positive during IOP indicating persistent dominance of fine-mode particles during all these days; however, it was the lowest on Diwali. It suggests that IOP is dominated by fine mode particle; but there is inclusion of other fine mode particles due to burning of fireworks during Diwali day. Babu and Moorthy [30] also found enhanced AODs during the event of firework, which was caused due to enhanced presence of black and organic carbon, generated by burning of different types of crackers and fireworks during

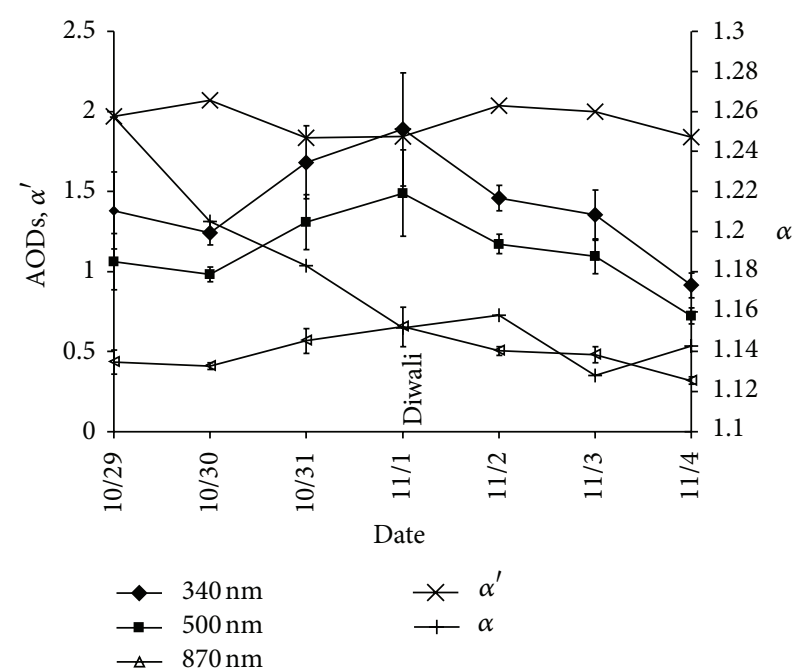

FIgURE 3: Day-to-day variability in AODs $(340 \mathrm{~nm}, 500 \mathrm{~nm}$, and $870 \mathrm{~nm}), \operatorname{AE}(\alpha, 340-870 \mathrm{~nm})$, and $\alpha^{\prime}$ for IOP.

Diwali. Singh et al. [12] have reported enhancement of 5.7\% and $5.5 \%$ for $\mathrm{AOD}_{340}$ and $\mathrm{AOD}_{500}$, respectively, during Diwali at Kanpur.

The variations in OPAC derived parameters, such as absorption coefficients, scattering coefficient, and SSA at $500 \mathrm{~nm}\left(\mathrm{SSA}_{500}\right)$, are also shown in Table 1. In general, the behavior of scattering coefficient was found similar to that of absorption coefficient and AOD, but it was different to that of AE. Scattering and absorption coefficients were found to be maximum (461.6 and $24.2 \mathrm{Mm}^{-1}$, resp.) on Diwali. The type of aerosols which contribute maximum to the scattering coefficient may include water-soluble inorganic species, such as sulfates and nitrates, arising from emissions of $\mathrm{SO}_{2}$ and $\mathrm{NO}_{x}$, and contributions from fossil fuel and biomass combustion sources. However, those aerosol types that contribute maximum to the absorbing coefficient may include BC, which is largely associated with firework [30].

Since scattering and absorbing type of aerosols are well mixed in the real atmosphere, their ultimate effect in terms of heating/cooling of the atmosphere depends on SSA of aerosol population. For the present case, minimum value of $S_{S A}$ $(\approx 0.95)$ was observed on November 02, the next day of Diwali. It suggests extended influence of absorbing particles emitted due to burning of fireworks during Diwali night $[10,11,30]$, which was affective till the next day. Absorbing aerosols are found to be associated with lower SSA values [35].

Spectral variations of average AOD, absorption coefficient, scattering coefficient, and SSA are shown in Figures 4(a)-4(d), respectively, for affected (October 31, November 01 and 02) and nonaffected (October 29, 30, November 03 and 04) periods. Significant differences in all the parameters were observed at all the wavelengths, for affected and nonaffected periods. It is found that AOD increased with the advent of Diwali and reached to its maximum value on November 01 (Diwali) for each wavelength (Figure 3 ). The burning of fireworks and crackers invariably contributes to the anthropogenic aerosols $[12,14]$ 
TABLE 1: Daily mean values of AOD, column water vapor and AE, absorption coefficients, scattering coefficients, and SSA from October 29, 2005, to November 04, 2005.

\begin{tabular}{|c|c|c|c|c|c|c|c|}
\hline Days (2005) & Category & $\mathrm{AOD}_{500}$ & $\mathrm{AE}_{340-870}$ & $\mathrm{CWV}(\mathrm{cm})$ & Abs. coeff. $_{500}\left(\mathrm{Mm}^{-1}\right)$ & Scatt. coeff. ${ }_{500}\left(\mathrm{Mm}^{-1}\right)$ & $\mathrm{SSA}_{500}$ \\
\hline October 29 & NA & 1.06 & 1.26 & 1.63 & 15.58 & 320.20 & 0.954 \\
\hline October 30 & NA & 0.98 & 1.21 & 1.34 & 15.01 & 303.20 & 0.953 \\
\hline October 31 & $\mathrm{AF}$ & 1.31 & 1.18 & 1.39 & 20.80 & 406.20 & 0.951 \\
\hline November 01 & $\mathrm{AF}$ & 1.49 & 1.15 & 1.61 & 24.23 & 461.60 & 0.950 \\
\hline November 02 & $\mathrm{AF}$ & 1.17 & 1.16 & 1.58 & 18.70 & 351.10 & 0.950 \\
\hline November 03 & NA & 1.10 & 1.13 & 1.51 & 17.03 & 338.10 & 0.952 \\
\hline November 04 & NA & 0.72 & 1.14 & 1.45 & 14.08 & 218.10 & 0.954 \\
\hline
\end{tabular}

NA: nonaffected, AF: affected.

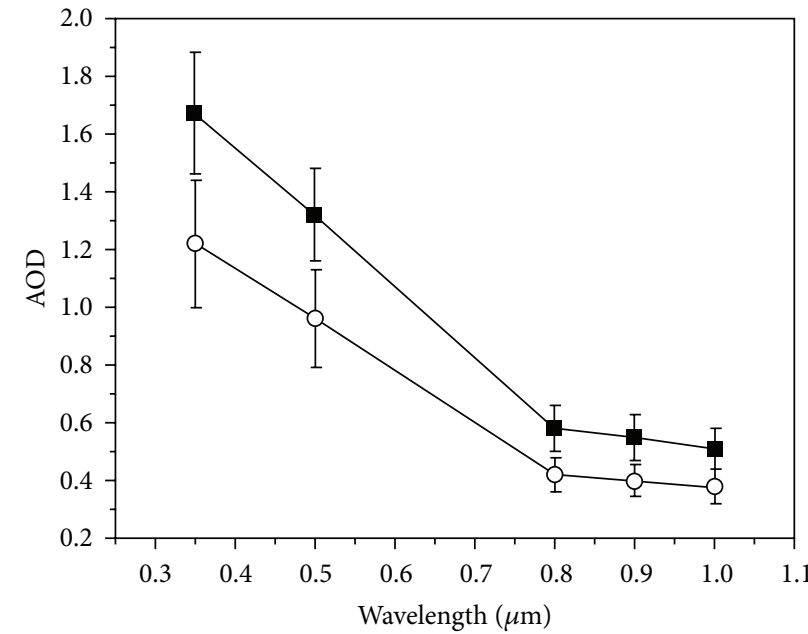

(a)

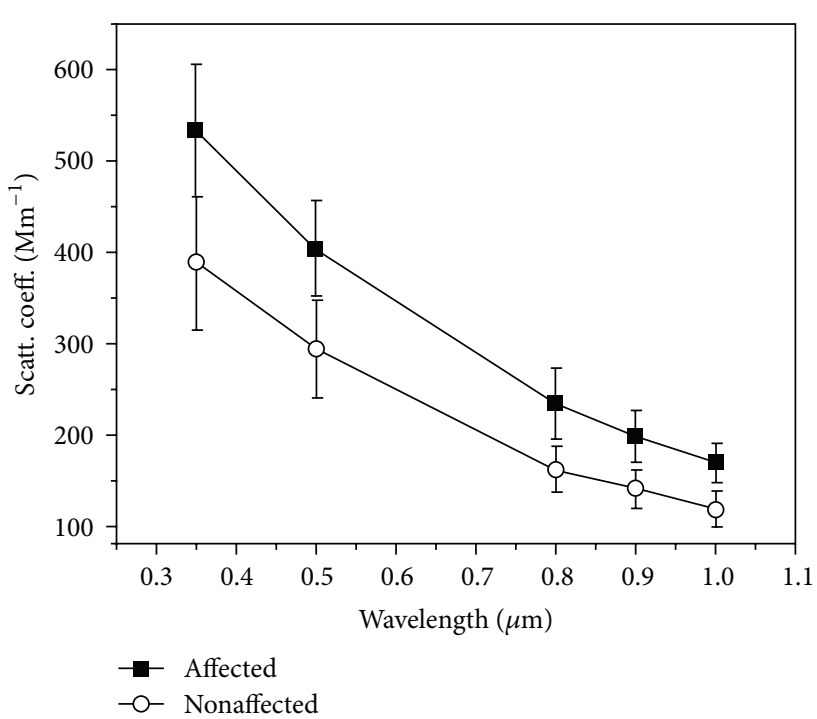

(c)

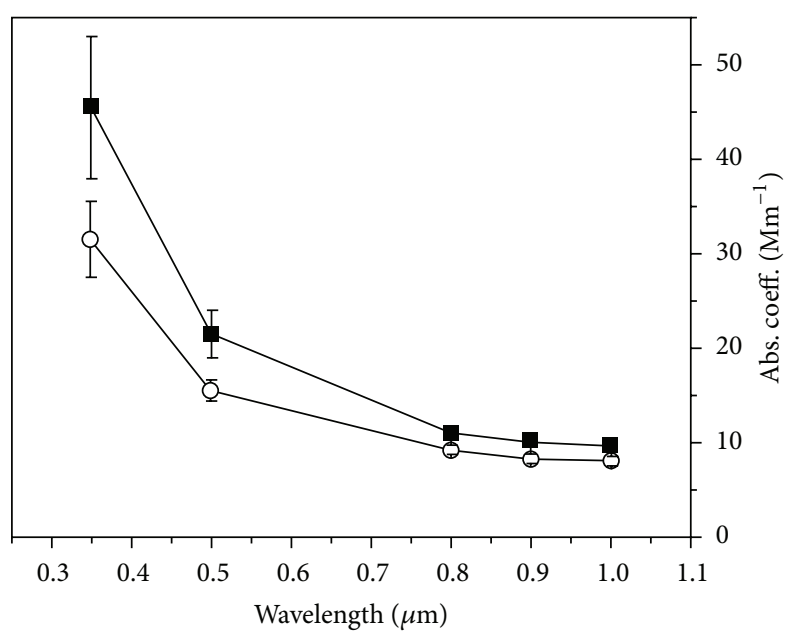

(b)

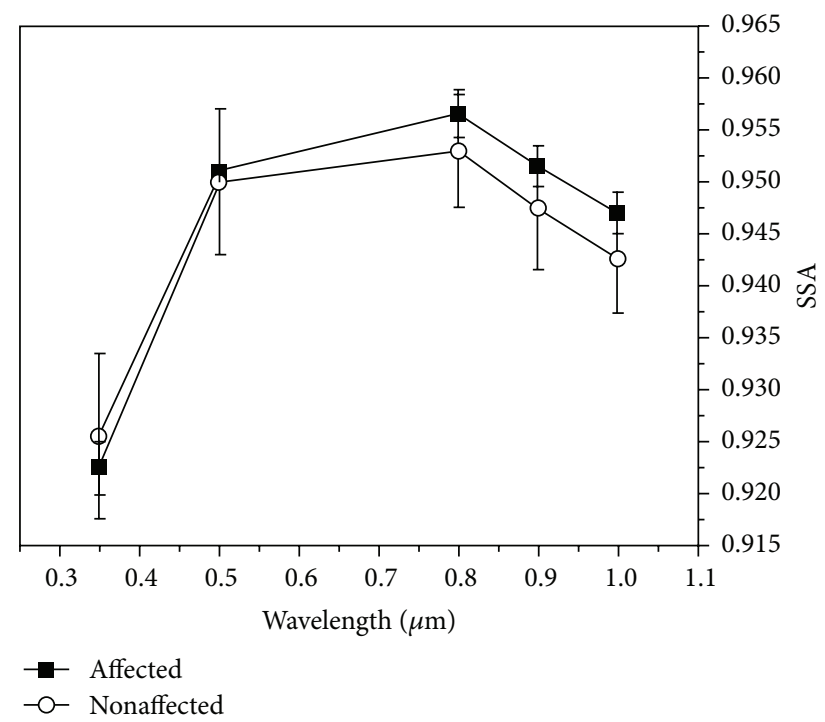

(d)

FIGURE 4: Spectral variation of (a) AOD, (b) absorption coefficient, (c) scattering coefficient, and (d) SSA for firework affected (October 31, November 01 and 02, 2005) and nonaffected periods (October 29, 30, November 03 and 04, 2005). 


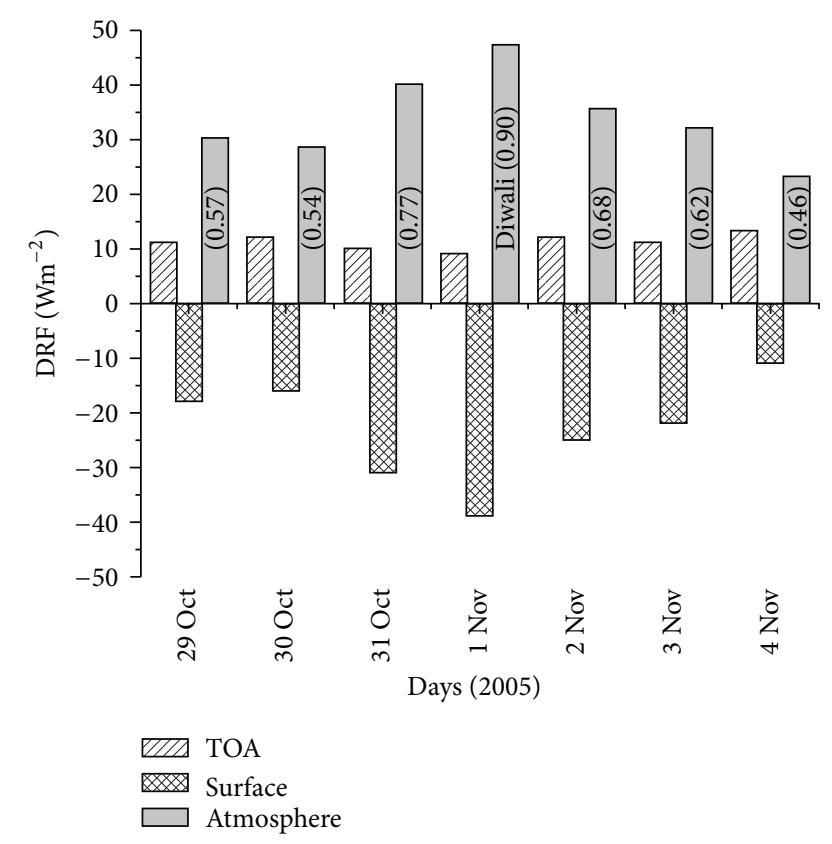

FIGURE 5: Day-to-day variability in the estimated direct radiative forcing at the TOA, surface, and in the atmosphere. The heating rate values are given in parentheses within respective bars.

and increases AODs [36]. AODs at all other wavelengths were found to increase for firework affected period (Figure 3). Average $\mathrm{AOD}_{500}$ for affected period shows the value of 1.3, which is $\sim 27 \%$ higher than the nonaffected period average. Similar increment in absorption coefficient $\left(21.2 \mathrm{Mm}^{-1}\right.$, increase of $27.4 \%)$ and scattering coefficient $\left(406 \mathrm{Mm}^{-1}\right.$, increase of 27.4\%) was also noticed for firework affected period in comparison to nonaffected period. It is to be mentioned here that, apart from the emissions of absorbing aerosols, different water-soluble species (like sulfate, nitrate, etc.) are also emitted from fire crackers burning, which are of scattering in nature. As a result, an enhancement in both absorption and scattering coefficients was observed. For the same period, however, AE had decreased by $6.2 \%$.

\subsection{Aerosol Radiative Forcing and Implications to Atmospheric} Heating Rate. Broadband aerosol direct radiative forcing (DRF) at the TOA, surface, and in the atmosphere for each day during IOP is shown in Figure 5. Negative value of surface forcing implies a net cooling effect, whereas positive value for TOA and within atmospheric implies a net warming effect. Significant day-to-day variability was observed in surface and atmospheric forcing values. The surface and atmospheric forcing was maximum $\left(-38\right.$ and $47 \mathrm{Wm}^{-2}$, resp.) on Diwali (November 01), whereas aerosol DRF at TOA was minimum $\left(9 \mathrm{Wm}^{-2}\right)$ on Diwali.

Average aerosol DRF estimated at TOA, surface, and in the atmosphere, during affected and nonaffected period, is shown in Figure 6. Magnitudes of forcing at TOA during the affected and nonaffected periods were $+10 \pm 1$ and $+12 \pm$ $1 \mathrm{Wm}^{-2}$, respectively; however, the forcing at surface was $-31 \pm 7$ and $-17 \pm 5 \mathrm{Wm}^{-2}$, respectively. These estimates

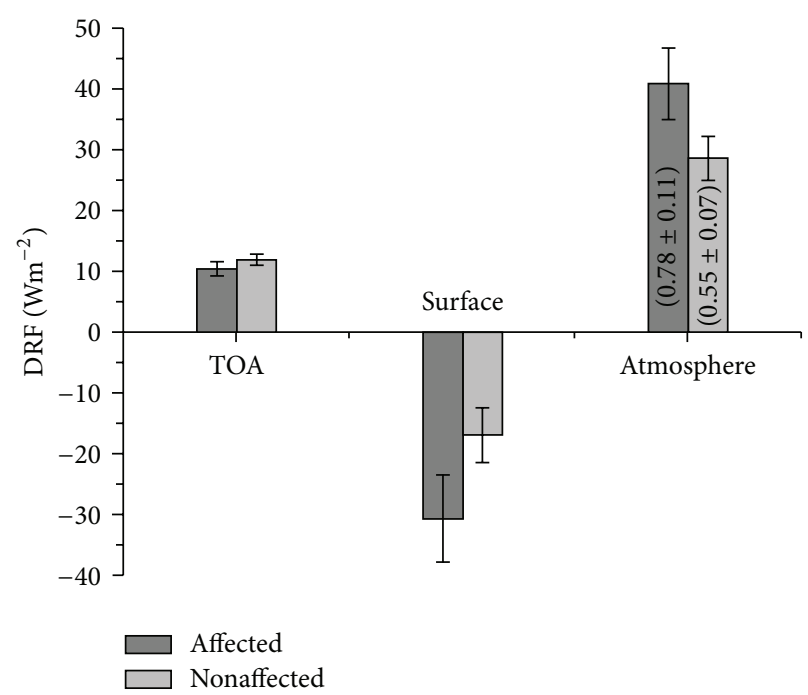

FIGURE 6: Comparison of estimated direct radiative forcing at the TOA, surface, and in the atmosphere for firework affected and nonaffected periods. Atmospheric heating rates are given in parentheses in the respective atmospheric forcing bars.

indicated an additional cooling of $2 \mathrm{Wm}^{-2}$ at the TOA $(\sim 20 \%)$ and $14 \mathrm{Wm}^{-2}$ at the surface ( 45\%) during firework affected period. Results could be due to enhanced loading of aerosols (absorbing and/or scattering type) over the station during firework period. Apart from the aerosol loading of absorption/scattering type aerosols, TOA and surface forcing are also sensitive to the albedo of the underlying surface [37]. The atmospheric forcing values during affected and nonaffected periods were estimated to be $+41 \pm 6$ and $+29 \pm 4 \mathrm{Wm}^{-2}$, respectively, which translate to an additional atmospheric warming of $+12 \mathrm{Wm}^{-2}$ during firework affected period.

The higher value of surface cooling and strong atmospheric heating in the atmosphere suggests their association with various aerosol properties, for example, size range and chemical composition of aerosol population, and raises several climatic issues $[4,9,38,39]$. An important aspect in this regard is the aerosol-generated atmospheric heating rates, which can be calculated from the first law of thermodynamics and hydrostatic equilibrium as

$$
\frac{\partial T}{\partial t}=\frac{g}{C_{p}} \frac{\Delta F}{\Delta P} \times 24(\text { hr } / \text { day }) \times 3600(\mathrm{sec} / \mathrm{hr}),
$$

where $\partial T / \partial t$ is heating rate in kelvin per day $\left(\mathrm{Kday}^{-1}\right), g / C_{p}$ is lapse rate, $g$ is acceleration due to gravity, $C_{p}$ is specific heat capacity of air at constant pressure $\left(1006 \mathrm{Jkg}^{-1} \mathrm{~K}^{-1}\right), \Delta F$ is atmospheric forcing due to aerosols, and $\Delta P$ is atmospheric pressure difference, which was considered to be $300 \mathrm{hPa}$ in the present case.

The estimated atmospheric daily heating rates during the study period are also shown in Figure 5 (in parenthesis). Heating rates are found to be increased to higher magnitudes $\left(0.90 \mathrm{Kday}^{-1}\right)$ on Diwali, which decreased afterwards to attain a lower magnitude $\left(0.46 \mathrm{Kday}^{-1}\right)$ on November 04. Average atmospheric heating rate was found to be 
$0.78 \pm 0.11 \mathrm{Kday}^{-1}$ for the affected period, which is approximately $30 \%$ higher than the nonaffected period (average about $0.55 \pm 0.07 \mathrm{Kday}^{-1}$ ). Considering the nonaffected period to represent normal atmospheric conditions, atmosphere is found to be heated up by $0.23 \mathrm{Kday}^{-1}$ due to enhanced aerosol loading related to burning of fireworks.

\section{Conclusions}

Increase of particulate number density is a common feature during fireworks burning event. During Diwali festival, fireworks are burnt in peak duration of 1-2 hours. An intensive observation program was conducted from October 29 to November 04, 2005 (Diwali on November 01.) at an urban location in Indo-Gangetic Plain, Varanasi, India, to study the optical properties of aerosols, radiative forcing, and atmospheric heating rates caused due to Diwali fireworks.

Study shows enhancement of $\sim 27 \%$ in the values of $\mathrm{AOD}_{500}$, absorption coefficients, and scattering coefficients for firework affected period in comparison to nonaffected period. Estimated top of atmosphere and surface forcing were found to be $+10 \pm 1$ and $-31 \pm 7 \mathrm{Wm}^{-2}$, respectively, for firework affected period and $+12 \pm 1$ and $-17 \pm 5 \mathrm{Wm}^{-2}$, respectively, for nonaffected periods. The estimated forcing caused an additional cooling of $\sim 20 \%$ at top of atmosphere and $\sim 45 \%$ at surface due to enhanced loading of aerosols (absorbing and/or scattering type) over the station during firework period. The resultant atmospheric forcing was $+41 \pm$ 6 and $+29 \pm 4 \mathrm{Wm}^{-2}$ during firework affected and nonaffected periods, respectively, which exerted an additional atmospheric heating of $\sim 0.23 \mathrm{Kday}^{-1}$ during firework affected period. In view of increasing population and extensive use of fireworks (and crackers) in major urban locations, the routine measurements of aerosols will certainly be helpful to understand the additional burden of aerosols caused due to fireworks burning. Such observations are also useful for understanding their impact on regional climate.

\section{Conflict of Interests}

The authors declare that there is no conflict of interests regarding the publication of this paper.

\section{Acknowledgments}

Authors Manoj K. Srivastava, B. P. Singh, and A. K. Singh are thankful for financial support from ISRO-ARFI and R. K. Singh is thankful to BHU and UGC for financial support. A. K. Singh, S. Tiwari, D. S. Bisht, and D. M. Lal are thankful to Director, IITM, for support and encouragement. IMD is acknowledged for proving supportive weather data. Authors are grateful to the anonymous reviewers for their constructive comments and suggestions towards the improvement of paper.

\section{References}

[1] V. Ramanathan, F. Li, M. V. Ramana et al., "Atmospheric brown clouds: hemispherical and regional variations in long-range transport, absorption, and radiative forcing," Journal of Geophysical Research D, vol. 112, no. 22, 2007.

[2] IPCC, Climate Change 2007: The Physical Science Basis, chapter 2, Cambridge University Press, Cambridge, UK, Contribution of Working Group I to the Fourth Assessment Report of the Intergovernmental Panel on Climate Change, 2007.

[3] A. K. Srivastava, D. S. Bisht, and S. Tiwari, "Boundary layer aerosol characteristics at Mahabubnagar during CAIPEEXIGOC: modeling the optical and radiative properties," Science of the Total Environment, vol. 468-469, pp. 1093-1102, 2014.

[4] J. Schneider and R. Eixmann, "Three years of routine Raman lidar measurements of tropospheric aerosols: backscattering, extinction, and residual layer height," Atmospheric Chemistry and Physics, vol. 2, no. 4, pp. 313-323, 2002.

[5] A. K. Srivastava, S. Singh, S. Tiwari, and D. S. Bisht, "Contribution of anthropogenic aerosols in direct radiative forcing and atmospheric heating rate over Delhi in the Indo-Gangetic Basin," Environmental Science and Pollution Research, vol. 19, no. 4, pp. 1144-1158, 2012.

[6] K. Ram, M. M. Sarin, and S. N. Tripathi, “Temporal trends in atmospheric PM2.5, PM10, elemental carbon, organic carbon, water-soluble organic carbon, and optical properties: impact of biomass burning emissions in the Indo-Gangetic Plain," Environmental Science and Technology, vol. 46, no. 2, pp. 686695, 2012.

[7] R. J. Charlson, J. E. Lovelock, M. O. Andreae, and S. G. Warren, "Oceanic phytoplankton, atmospheric sulphur, cloud albedo and climate," Nature, vol. 326, no. 6114, pp. 655-661, 1987.

[8] R. J. Charlson, J. Langner, H. Rodhe, C. B. Leovy, and S. G. Warren, "Perturbation of the northern hemisphere radiative balance by backscattering from anthropogenic sulfate aerosols," Tellus, vol. 43, no. 4, pp. 152-163, 1991.

[9] S.-W. Kim, S.-C. Yoon, A. Jefferson et al., "Observation of enhanced water vapor in Asian dust layer and its effect on atmospheric radiative heating rates," Geophysical Research Letters, vol. 31, no. 18, 2004.

[10] F. Drewnick, S. S. Hings, J. Curtius, G. Eerdekens, and J. Williams, "Measurement of fine particulate and gas-phase species during the New Year's fireworks 2005 in Mainz, Germany," Atmospheric Environment, vol. 40, no. 23, pp. 4316-4327, 2006.

[11] B. Wehner, A. Wiedensohler, and J. Heintzenberg, "Submicrometer aerosol size distributions and mass concentration of the millennium fireworks 2000 in Leipzig, Germany," Journal of Aerosol Science, vol. 31, no. 12, pp. 1489-1493, 2000.

[12] R. P. Singh, S. Dey, and B. Holben, "Aerosol behaviour in Kanpur during Diwali festival," Current Science, vol. 84, no. 10, pp. 13021304, 2003.

[13] U. C. Kulshrestha, T. Nageswara Rao, S. Azhaguvel, and M. J. Kulshrestha, "Emissions and accumulation of metals in the atmosphere due to crackers and sparkles during Diwali festival in India," Atmospheric Environment, vol. 38, no. 27, pp. 44214425, 2004.

[14] S. Tiwari, D. M. Chate, M. K. Srivastava et al., "Statistical evaluation of $\mathrm{PM}_{10}$ and distribution of $\mathrm{PM}_{1}, \mathrm{PM}_{2.5}$, and $\mathrm{PM}_{10}$ in ambient air due to extreme fireworks episodes (Deepawali festivals) in megacity Delhi," Natural Hazards, vol. 61, no. 2, pp. 521-531, 2012.

[15] J. M. Becker, S. Iskandrian, and J. Conkling, "Fatal and nearfatal asthma in children exposed to fireworks," Annals of Allergy, Asthma and Immunology, vol. 85, no. 6, pp. 512-513, 2000. 
[16] T. Moreno, X. Querol, A. Alastuey et al., "Recreational atmospheric pollution episodes: inhalable metalliferous particles from firework displays," Atmospheric Environment, vol. 41, no. 5, pp. 913-922, 2007.

[17] K. Ravindra, S. Mor, and C. P. Kaushik, "Short-term variation in air quality associated with firework events: a case study," Journal of Environmental Monitoring, vol. 5, no. 2, pp. 260-264, 2003.

[18] A. K. Attri, U. Kumar, and V. K. Jain, "Formation of ozone by fireworks," Nature, vol. 411, no. 6841, p. 1015, 2001.

[19] N. K. Lodhi, S. N. Beegum, S. Singh, and K. Kumar, "Aerosol climatology at Delhi in the western indo-gangetic plain: microphysics, long-term trends, and source strengths," Journal of Geophysical Research, vol. 118, no. 3, pp. 1361-1375, 2013.

[20] M. Morys, F. M. Mims III, S. Hagerup et al., "Design, calibration, and performance of MICROTOPS II handheld ozone monitor and Sun photometer," Journal of Geophysical Research D, vol. 106, no. 13, pp. 14573-14582, 2001.

[21] A. Ångström, “The parameters of atmospheric turbidity," Tellus, vol. 16, pp. 64-75, 1964.

[22] A. K. Srivastava, P. C. S. Devara, Y. J. Rao, Y. Bhavanikumar, and D. N. Rao, "Aerosol optical depth, ozone and water vapor measurements over Gadanki, a tropical station in peninsular India," Aerosol and Air Quality Research, vol. 8, no. 4, pp. 459476, 2008.

[23] G. V. Pawar, P. C. S. Devara, S. D. More, P. Pradeep Kumar, and G. R. Aher, "Determination of aerosol characteristics and direct radiative forcing at Pune," Aerosol and Air Quality Research, vol. 12, pp. 1166-1180, 2012.

[24] M. Hess, P. Koepke, and I. Schult, "Optical properties of aerosols and clouds: the software package OPAC," Bulletin of the American Meteorological Society, vol. 79, no. 5, pp. 831-844, 1998.

[25] P. Alpert, Y. J. Kaufman, Y. Shay-El et al., "Quantification of dust-forced heating of the lower troposphere," Nature, vol. 395, no. 6700, pp. 367-370, 1998.

[26] P. Ricchiazzi, S. Yang, C. Gautier, and D. Sowle, "SBDART: a research and teaching software tool for plane-parallel radiative transfer in the earth's atmosphere," Bulletin of the American Meteorological Society, vol. 79, no. 10, pp. 2101-2114, 1998.

[27] A. K. Prasad, S. Singh, S. S. Chauhan, M. K. Srivastava, R. P. Singh, and R. Singh, "Aerosol radiative forcing over the Indo-Gangetic plains during major dust storms," Atmospheric Environment, vol. 41, no. 29, pp. 6289-6301, 2007.

[28] S. More, P. Pradeep Kumar, P. Gupta, P. C. S. Devara, and G. R. Aher, "Comparison of aerosol products retrieved from AERONET, MICROTOPS and MODIS over a tropical urban city, Pune, India," Aerosol and Air Quality Research, vol. 13, pp. 107-121, 2013.

[29] G. Pandithurai, R. T. Pinker, P. C. S. Devara, T. Takamura, and K. K. Dani, "Seasonal asymmetry in diurnal variation of aerosol optical characteristics over Pune, western India," Journal of Geophysical Research D, vol. 112, no. 8, Article ID D08208, 2007.

[30] S. S. Babu and K. K. Moorthy, "Anthropogenic impact on aerosol black carbon mass concentration at a tropical coastal station: a case study," Current Science, vol. 81, no. 9, pp. 1208-1214, 2001.

[31] T. F. Eck, B. N. Holben, J. S. Reid et al., "Wavelength dependence of the optical depth of biomass burning, urban, and desert dust aerosols," Journal of Geophysical Research D, vol. 104, no. 24, pp. 31333-31349, 1999.
[32] N. T. O’Neill, T. F. Eck, B. N. Holben, A. Smirnov, A. Royer, and Z. Li, "Optical properties of boreal forest fire smoke derived from Sun photometry," Journal of Geophysical Research, vol. 107, no. 11, pp. AAC 6-1-AAC 6-19, 2002.

[33] D. G. Kaskaoutis, H. D. Kambezidis, A. D. Adamopoulos, and P. A. Kassomenos, "On the characterization of aerosols using the Ångström exponent in the Athens area," Journal of Atmospheric and Solar-Terrestrial Physics, vol. 68, no. 18, pp. 2147-2163, 2006.

[34] K. Soni, S. Singh, T. Bano, R. S. Tanwar, S. Nath, and B. C. Arya, "Variations in single scattering albedo and angstrom absorption exponent during different seasons at Delhi, India," Atmospheric Environment, vol. 44, no. 35, pp. 4355-4363, 2010.

[35] O. Dubovik, B. Holben, T. F. Eck et al., "Variability of absorption and optical properties of key aerosol types observed in worldwide locations," Journal of the Atmospheric Sciences, vol. 59, no. 3, pp. 590-608, 2002.

[36] B. M. Vyas and V. Saraswat, "Studies of atmospheric aerosol's parameters during pre-diwali to post-Diwali festival period over Indian semi arid station i.e., Udaipur," Applied Physics Research, vol. 4, no. 2, pp. 40-55, 2012.

[37] J. Meier, I. Tegen, B. Heinold, and R. Wolke, "Direct and semidirect radiative effects of absorbing aerosols in Europe: results from a regional model," Geophysical Research Letters, vol. 39, no. 9, 2012.

[38] J. T. Houghton, Y. Ding, D. J. Griggs et al., Eds., Climate Change 2001: The Scientific Basis, Cambridge University Press, New York, NY, USA, 2001.

[39] Y. J. Kaufman, O. Boucher, D. Tanre, M. Chin, L. A. Remer, and T. Takemura, "Aerosol anthropogenic component estimated from satellite data," Geophysical Research Letters, vol. 32, no. 17, 2005. 

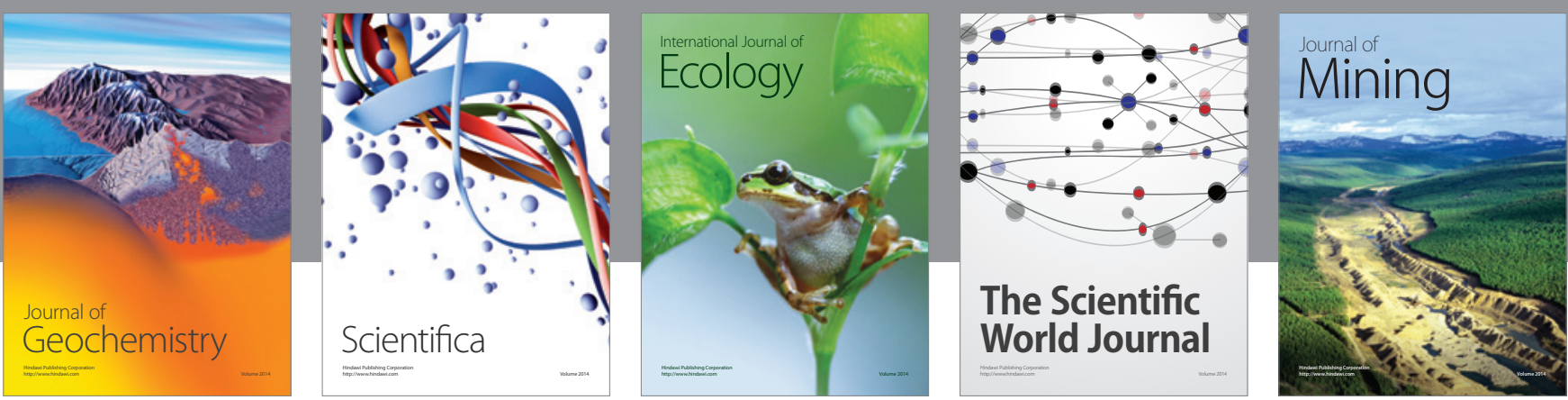

The Scientific World Journal
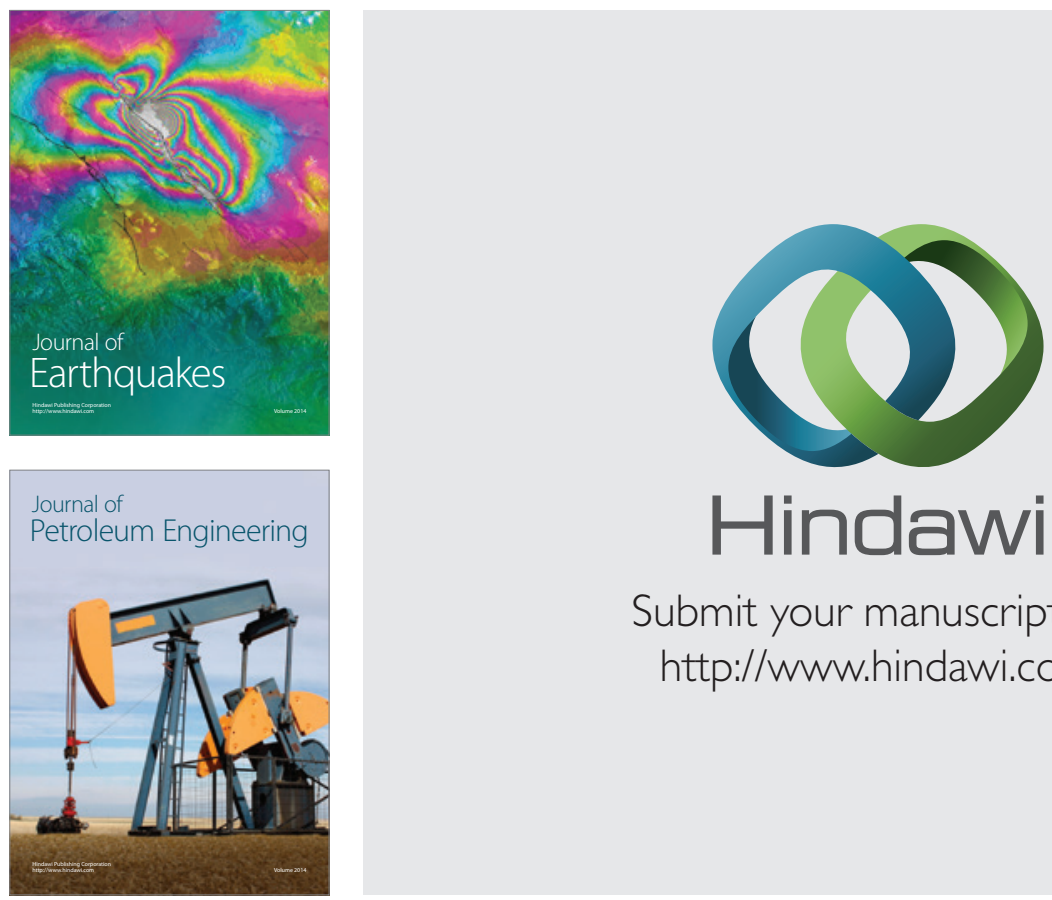

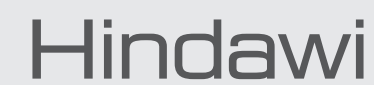

Submit your manuscripts at

http://www.hindawi.com
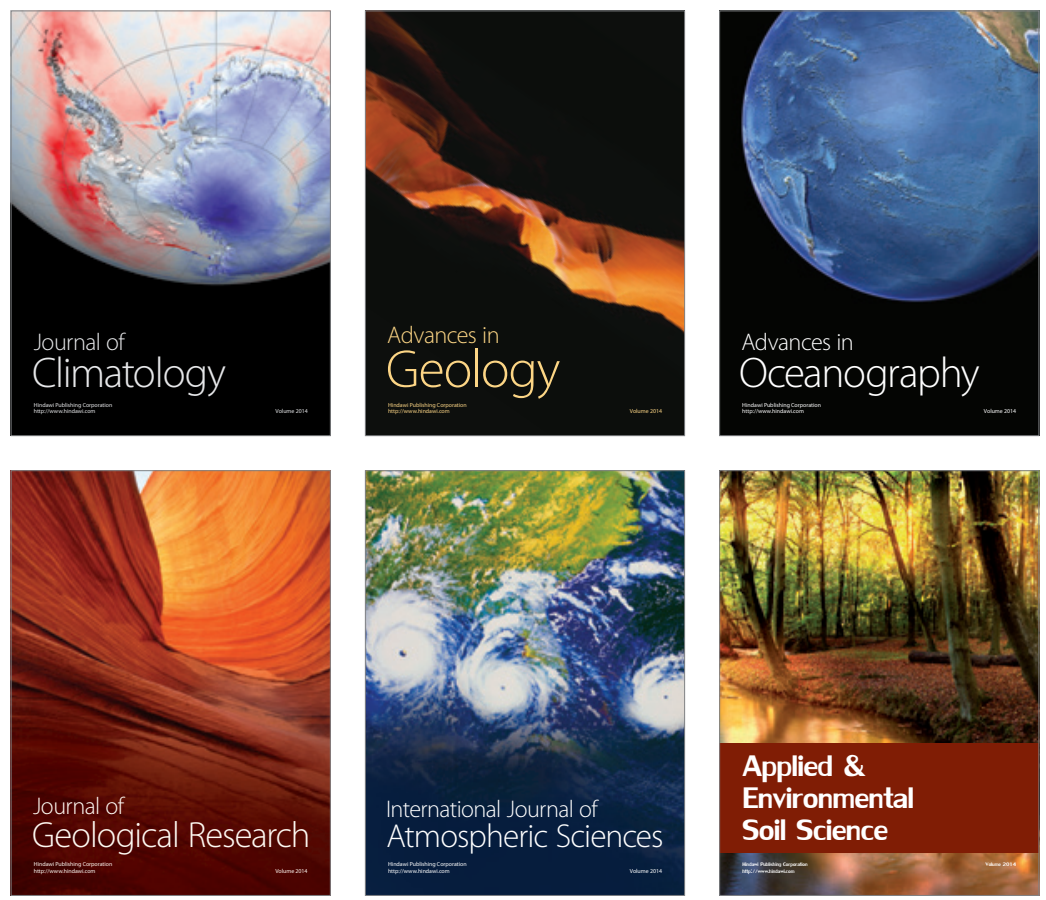
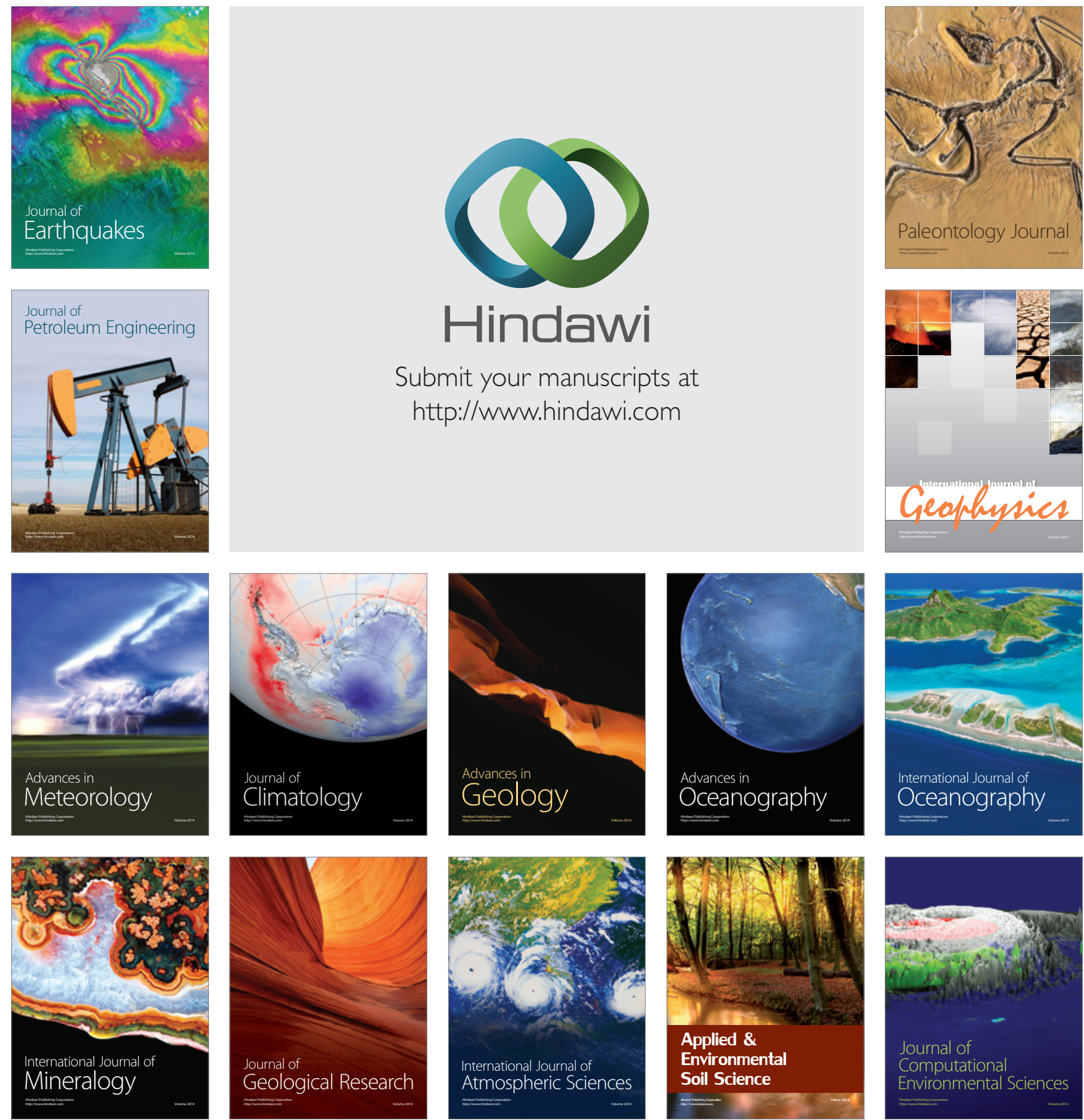